\title{
Exemplo e ameaça: a consolidação da Ditadura no Brasil nas páginas da revista argentina Confirmado (1965-1966)
}

\author{
Example and threat: the consolidation of the \\ Dictatorship in Brazil through the pages of \\ Argentinian magazine Confirmado (1965-1966) \\ Ejemplo y amenaza: la consolidación de la \\ Dictadura en Brasil en las páginas de la \\ revista argentina Confirmado (1965-1966)
}

Helder Gordim da Silveira*

Resumo: Este artigo analisa a forma pela qual a revista argentina Confirmado representou a consolidação do golpe civil-militar de 1964 no Brasil enquanto notícia/ acontecimento. Enfatiza-se como este discurso jornalístico, mobilizando imagens e interpretações recorrentes, possivelmente atuou como um importante componente de uma ideologia da solução autoritária frente à crise política e institucional que crescia na região desde, pelo menos, a década de 1950.

Palavras-chave: Ditadura Civil-Militar; Argentina-Brasil; revista Confirmado

Abstract: This paper analyses the way by which the Argentinian magazine Confirmado represented the consolidation of the 1964 civilian-military coup in Brazil as news/ fact. It is underlined how that journalistic discourse, mobilizing recurrent images and interpretations, possibly acted as an important component of an ideology of authoritative solution before the political and institutional crises that were growing in the region since at least the decade of 1950 .

Keywords: Civilian-Military Dictatorship; Argentina-Brazil; Confirmado magazine

Resumen: Este artículo analiza la forma en que la revista argentina Confirmado representó la consolidación del golpe civil-militar de 1964 en Brasil como noticias/ factos. Se hace hincapié en como que este discurso periodístico, con la movilización

* Doutor em História. Professor do Departamento de História e do Programa de Pós-Graduação em História da PUCRS. < helders@pucrs.br>< <dados biográficos/biographic data> 
de imágenes e interpretaciones recurrentes, posiblemente sirvió como un componente importante de una ideología de solución autoritaria frente a la crisis política e institucional que creció en la región desde al menos la década de 1950.

Palabras claves: Dictadura civil-militar; Argentina y Brasil; revista Confirmado

\section{Introdução}

O presente artigo tem como pressuposto básico a consideração segundo a qual os mass media, particularmente a imprensa informativa empresarial constituem-se em atores complexos que desempenham papel de relevância central na esfera política interna dos Estados e nas relações internacionais contemporâneas. Tem-se fundamentalmente em conta que, por meio dos mecanismos, instituições bem como estruturas técnicas e mercadológicas de difusão da comunicação de massa (THOMPSON, 1995, p. 287-295), circulam mundialmente e no interior dos espaços regionais e nacionais, as formas discursivas e imagéticas que podem tornar-se hegemônicas - considerando-se o espaço de conflito sociopolítico em que pode constituir-se o meio de comunicação específico e/ou a variedade destes - na representação e na constituição mesma da realidade supostamente objetiva do mundo assim constituído, fundada na categoria notícia, basilar do discurso jornalístico.

A designação imprensa informativa empresarial é aqui uma referência genérica aos jornais diários e às revistas ou magazines com forma, conteúdo e natureza organizacional resultantes da transição que se verifica grosso modo a partir das décadas finais do século dezenove, com origem marcada nos Estados Unidos, mas com reflexos quase imediatos na Europa e na América Latina. Tratava-se da passagem de uma imprensa essencialmente ligada às disputas ideológicas e partidárias da arena pública e estatal ou ao campo literário, para uma atividade jornalística que vinha a reivindicar independência e autonomia em relação àquelas disputas, fundada na perspectiva de profissionalização, de empreendimento empresarial e de objetividade informativa (GOLDSTEIN, 1987).

Tal processo de transição não representou, todavia, o abandono da noção liberal clássica da imprensa como tribuna de discussão civilizada das diferentes posições políticas, de alguma forma, assim, análoga ao Parlamento, sem compor o poder estatal e sem submeter-se aos mecanismos estritamente partidários. Ao contrário, a construção da autonomia do campo jornalístico moderno (THOMPSON, 1995, 
p. 221-266) e o fortalecimento acelerado de seus capitais econômico e simbólico, parecem ter concorrido para o reforço da reivindicação doutrinária em torno da assim denominada "liberdade de imprensa", identificada progressivamente à noção clássica de liberdade de expressão e de informação associada ao Estado de Direito moderno e ao espaço público que este parecia assim garantir, no âmbito da sociedade civil.

Tem-se aqui, portanto, em conta que as formas de referência deste discurso sobre a esfera política e seus conflitos, nacionais e internacionais, no caso presente o golpe de 1964 e seus desdobramentos no Brasil noticiados na Argentina, são geralmente embasadas, implícita ou explicitamente, nos conceitos essenciais da matriz doutrinária liberal, que surge ali naturalizada (THOMPSON, 1995, p. 87-89) constituindo uma forma de liberalismo profissional, típico do campo.

Este tipo de órgão da imprensa torna-se, assim, ator essencial nas políticas interna e externa de um país, ao constituir-se na forma pela qual uma dada visão do espaço internacional, em seus atores, conflitos e padrões de estruturação, apresente-se como hegemônica, associada a variadas posições de poder, ou a confrontos em torno deste, no espaço público nacional, frente aos quais aquela forma de imprensa busca posicionar-se, segundo suas especificidades institucionais e campo diferenciado de interação social (ALLEYNE, 1995; FREDERICK, 1993; PIZARRO, 2008; THUSSU, 2000).

É nesse sentido que aqui se busca pensar o órgão jornalístico, especificamente a revista argentina Confirmado, como ator político complexo ao noticiar para seu público a institucionalização da ordem ditatorial de1964 no Brasil. Para tanto, tem-se como perspectiva teórica, por um lado, os termos da discussão posta por Pierre Nora (1979) em texto célebre a respeito da natureza do acontecimento como categoria constituinte da história contemporânea e, por outro, a tradição analítica relativa ao conceito de ideologia, atualizado em John Thompson (1995, p.43-89), como forma geral de interpretação de um possível papel histórico das formas simbólicas no universo do político. Refere nesse sentido o autor que "a análise da ideologia (...) está primeiramente interessada com as maneiras como as formas simbólicas se entrecruzam com relações de poder" (THOMPSON, 1995, p. 75) e que "estudar a ideologia é estudar as maneiras como o sentido serve para estabelecer e sustentar relações de dominação", sendo que "fenômenos ideológicos são fenômenos simbólicos significativos desde que eles sirvam, em circunstâncias sócio-históricas específicas, para estabelecer e sustentar relações de dominação" (THOMPSON 1995, p. 76). Sempre nessa 
direção, importa destacar que

Caracterizar fenômenos simbólicos como ideológicos não coloca, necessariamente, sobre o analista, o encargo de demonstrar que os fenômenos assim caracterizados são, em certo sentido, 'falsos'. O que nos interessa (...) não é (...) a verdade ou a falsidade das formas simbólicas: antes interessam-nos as maneiras como essas formas servem, em circunstâncias particulares, para estabelecer e sustentar relações de dominação (THOMPSON, 1995, p. 76-77).

Nesse sentido, considerando a questão do acontecimento acima posta e a possibilidade de interpretar a construção deste no discurso jornalístico moderno como ideologia, é aqui seguida a posição de Muniz Sodré quanto à centralidade da categoria notícia neste discurso:

o jornalismo (...) mobiliza diferentes tipos de discurso, mas a sua moderna centralidade conceitual apoia-se na notícia. E esta forma de captação e comunicação do fato é uma dessas estratégias cuja mitologia liberal-mercadológica costuma fazer esquecer os procedimentos retóricos e imaginosos que presidem à construção do acontecimento (SODRÉ, 2009, p. 15).

Igualmente a respeito dessa relação essencial acontecimento-notícia que embasa o discurso jornalístico aqui tratado, refere por seu turno Miquel Alsina:

hay que puntualizar que un acontecimiento no es una realidad objetiva, exterior y ajena al sujeto perceptor del mismo (...). La teoría de la construcción social de la realidad (...) hace referencia a la vida cotidiana. (...) los acontecimientos son 'realidades' históricas determinadas socioculturalmente, como puede apreciarse en la variación histórica que en los mismos se han producido. En la actualidad los mass media establecen unos parámetros para delimitar los hechos que cabe considerar como acontecimientos (ALSINA, 1996, p. 16-17).

Assim, na esteira dos fundamentos conceituais propostos pelos referidos autores, entende-se aqui o discurso jornalístico moderno essencialmente como narrativa embasada na categoria notícia, a qual, mobilizando formas discursivas diversas, constitui o que no plano do espaço público pode assim se situar como acontecimento, dentro de certos padrões de racionalização (THOMPSON, 1995, p. 82-83) que podem tornar-se hegemônicos. 
Nesse sentido, sustenta-se que tais formas de construção de um acontecimento, particularmente em um país estrangeiro, operadas pelos meios de comunicação de massa e "afinado com a estrutura ideológica do sistema informativo, cuja forma mais evidente é a presumida transparência da realidade" (SODRÉ, 2009, p. 16. Grifo no original), podem constituir-se para certa comunidade de leitores, como racionalizações de uma ameaça a ser evitada, um exemplo a ser seguido ou uma manifestação de tendência posta como inevitável.

Assim, Brasil e Argentina representam-se mutuamente como os países mais poderosos no cenário sul-americano e, eventualmente, como polos de uma disputa pela supremacia estratégica em tal espaço, ao menos até os anos 1970 (SCENNA, 1976; BANDEIRA, 1993; BANDEIRA, 2003; FAUSTO; DEVOTO, 2004; FROTA, 1991). Nessa perspectiva, constroem-se, nos círculos diplomáticos e intelectuais, na imprensa informativa empresarial, aqui destacada, e em outras esferas de produção discursiva, representações constituintes de identificação e contraste em ambos os países, relativas a acontecimentos e/ou cursos de longo prazo de suas respectivas ordens socioeconômicas e políticas internas.

Especificamente na conjuntura da década de 1960, contexto aqui considerado, Brasil e Argentina atravessam os impasses condicionados pela crise dos respectivos modelos de modernização socioeconômica oriundos das eras varguista e peronista, diante do cenário da Guerra Fria, no qual a Revolução Cubana atuava como um extraordinário catalisador de tensões (CAVLAK, 2007; RAPOPORT; LAUFER, 2000).

\section{Confirmado e o Campo Jornalístico Argentino}

O surgimento de Confirmado dá-se em um contexto de abertura e de marcada internacionalização econômica e cultural do pós-1955, com a intervenção militar que depusera Perón, a autodenominada Revolución Libertadora, e que então marcava a vida nacional argentina, ou pelo menos de Buenos Aires e das províncias mais industrializadas. Sobre tal contexto, refere Miguel Angel Taroncher:

durante el gobierno de Arturo Frondizi (1958-1962), Argentina no sólo transnacionalizó su economia, sino que abandonó - aceleradamente - el aislamiento que habían propiciado, como parte de su política cultural, los dos primeros gobiernos peronistas. Este processo de apertura al exterior (...) se verificó a través de un considerable aumento en el consumo de revistas extranjeras y en un 'boom' editorial de publicaciones periodísticas (TARONCHER, 2004, p. 146). 
Na mesma direção aponta Elena Piñero:

la ruptura del aislamiento enfrentó a los argentinos con un mundo complejo y cambiante al que deseaban integrarse y dio origen a un acelerado proceso de renovación científica, técnica y cultural cuyo principal foco fué la Universidad. Especial relevancia adquirieron las profesiones vinculadas a nuevas disciplinas como administración de empresas, sociologia y psicologia (PIÑERO, 2002, p. 3).

Jorge Luis Bernetti igualmente situa este contexto sociocultural argentino nesses termos gerais, referindo-se particularmente ao surgimento da revista Primera Plana em 1962, a criação maior de Jacobo Timerman, que será igualmente o diretor-fundador de Confirmado:

constituyó (...) una expresión del complejo y contraditório clima cultural de la época signado contraditoriamente por fuertes giros regresivos y ascendentes movimientos revolucionários. Su nacimiento quedó inscrito (...) 'en el marco de las nuevas inversiones de capitales extranjeros, de la vigorosa movilización del mercado publicitario, de la internacionalización de los contenidos y tecnicas gráficas'. Así, junto al desarollo de las revistas de impacto gráfico, como Gente o Siete Dias, se produjo 'el de los semanários de opinión y información que se inspiran em las formulas de Time o L'Express (...) destinados de manera preferente a uma franja de público más restringida y con mayor nivel socioeconómico' (BERNETTI, 1998, s/p).

De fato, tal contexto apresentava agudo contraste com a época peronista no que toca às relações entre os campos político e jornalístico. Quando chegou à presidência, em 1946, Perón contava apenas com o apoio declarado do diário La Época. Quando de sua queda, em 1955, o líder justicialista controlava uma grande cadeia nacional de jornais, composta por La Razón, Democracia, El Laborista, La Época e Notícias Gráficas, além de cinco diários do interior e outros órgãos que não se articulavam oficialmente à cadeia peronista, mas mantinham posições mais ou menos sistemáticas de apoio à linha política do regime (SIRVÉN, 2011; DA ORDEN; PIRRO, 2007). Faziam, todavia, oposição sistemática e sofriam com a censura, os grandes diários portenhos, como La Nación e La Prensa.

A cobertura da institucionalização da ditadura de 1964 nas páginas de Confirmado, por seu turno, insere-se em um contexto particularmente dramático das relações entre os campos político e jornalístico na Argentina da democracia tutelada pelos militares - ainda marcados 
pela cisão, simbolizada pelas cores de exercícios de guerra, entre azules, legalistas e adeptos de uma solução frentista que incorporasse ao sistema político um "peronismo sem Perón" e colorados, que defendiam uma proscrição radical do peronismo através de uma ordem ditatorial mais diretamente controlada pelo poder militar (DE RIZ, 2000, p. 30-42; GAMBINI, 2008, p. 104-106; POTASH, 1994, p. 77-99). Em tal contexto, o peronismo eleitoralmente proscrito, em suas faces política e sindical, persistia uma força ativa e organizada, em que pese as fortes divisões internas que apresentava diante do exílio ativo de seu líder maior na Espanha (LLAIRÓ, 2007; DE RIZ, 2000; GAMBINI, 2008; SPINELLI, 2003; ROMERO, 2004; DONGHI, 2000; GOLDWERT, 1972; SCIRICA, 2008). O governo de Arturo Illia, da Unión Cívica Radical del Pueblo (UCRDP), um dos partidos que resultara da divisão do radicalismo, originara-se em uma vitória eleitoral contestada e frágil, em 1963 (SÁNCHEZ, 1983), e no interior da crise que se abrira pela deposição de Frondizi e pelo consequente fracasso do chamado frentismo, coalizão que aquele líder da Unión Cívica Radical Intransigente (UCRI) tentara articular com uma fração do peronismo e parte das Forças Armadas, que se articularia sob a denominação azules (LLAIRÓ; SIEPE, 2003; CANTIS, 1995).

Nesse quadro, muitos autores chegam a sustentar a existência de um golperiodismo contra o governo de Arturo Illia, (TARONCHER, 2009; POTASH, 1994, SANCHEZ, 1983; ULANOVSKY, 2005; DÍAZ, 2007; PANDOLFI; GIBAJA, 2008), fundado em prática abertamente conspiratória e/ou na difusão de uma forma de discurso anticomunistaantipopulista, posto como modernizador, o que teria um desfecho com o golpe de 1966 liderado por Juan Carlos Ongania. Os exemplos mais destacados nessas perspectivas de análise são as referidas revistas semanais Primera Plana e Confirmado, as duas criações de Timerman, mas igualmente se destacam a virulência dos editoriais e a oposição sistemática contra o governo Illia dos grandes diários, como La Nación e La Prensa, bem como o papel de colunistas desses diversos órgãos, tais como Juan José Guiraldes, Mariano Montemayor e Mariano Grondona.

Nesse contexto crítico e de forte expansão do campo jornalístico, em 7 de maio de 1965 aparecia o primeiro número da revista Confirmado, sob a direção do já consagrado criador de Primera Plana, Jacobo Timerman, que havia deixado esta revista e seu grupo editorial em julho de 1964, sem expor os motivos profundos da decisão a seus principais colaboradores (ULANOVSKY, 2005, p. 228). 
Jacobo Timerman, nascido a 6 de janeiro de 1923 em Bar, uma pequena cidade da Ucrânia, chegou à Argentina em outubro de 1928. Sofrendo uma infância de privações, conseguiu concluir os estudos secundários e ingressou no curso de admissão a Engenharia, na Universidade Nacional de La Plata. Abandonou os estudos e passou a sobreviver de pequenos empregos em vários pontos da Argentina. Seu primeiro contato significativo com o jornalismo foi a participação na revista semanal Qué, apontada como precursora do estilo de Primera Plana, havendo trabalhado posteriormente em Noticias Gráficas. Após 1955, trabalhou em La Razon, Clarin, El Nacional e dirigiu El Mundo. Após fundar e dirigir Primera Plana, teve destacada atuação na imprensa argentina. Sobre Timerman, refere Miguel Angel Taroncher: "dentro del periodismo argentino, Timerman, gañador del premio Pullitzer, es considerado una de sus más brillantes personalidades. Si bien participó de la extendida cultura política que consideraba a los golpes de estado como instancias de resolución de la problemática nacional, en 1976 (...) será secuestrado y torturado por la nueva dictadura militar" (1998, p. 152).

Seguindo o estilo New Journalism de sua então já célebre criação anterior, a qual pretendia eventualmente superar no mercado jornalístico, Timerman apresentava seu novo semanário como uma "revista semanal de notícias". Carlos Ulanovsky sublinha que "en una plataforma de propósitos editoriales decía que intentaria presentar 'sin escamoteos ni subterfúgios la actualidad del mundo contemporáneo"” (ULANOVSKY, 2005, p. 241). Na primeira edição, afirmava Timerman: "queda así estabelecida la teoria actual y futura de Confirmado: brindar a los lectores toda la información, sin pretender influir más que con la presentación cruda - y por lo tanto apasionada - de los hechos" (in TARONCHER, 2009, p. 174).

No que toca ao posicionamento político do periódico na arena nacional, Carlos Ulanovsky afirma: "lo que nunca se olvidó de la revista fue su asociación con las posiciones que alentaron y provocaron el golpe de estado que derrocó a Illia" (2005, p. 241). O mesmo posicionamento, conforme referido, apresentava a criação anterior de Timermman, Primera Plana, com a qual Confirmado igualmente compartia o estilo fundado no New Journalism. Todavia, segundo atestaria posteriormente Abrasha Rotemberg, assessor econômico, colaborador e amigo de Timerman, Confirmado não logrou ser mais do que "un pálido reflejo de Primera Plana, un autoplagio en tono menor, (...) una sombra" (in TARONCHER, 2009, p. 179). Sobre a questão, Miguel Angel Taroncher 
conclui que "a pesar de cumplir con muchos de los requisitos que aseguraban un proyecto editorial exitoso, algo falló: el 'aura' de Primera Plana no pudo ser superado, ni siquiera alcanzado" (2009, p. 179).

Graciela Mochkofsky assim examina o alto staff e os principais articulistas colaboradores de Confirmado, os quais, segundo a autora, compunham um grupo com representantes dos três setores que, sempre conforme sua análise, projetavam o golpe de estado: a facção azul do exército, o referido frentismo frondizista e o que denomina establishment econômico:

por el primero, estaban el ex ministro de interior de Guido, Rodolfo Martinez; el ex canciller frondizista Carlos Florit; el teniente coronel retirado Alberto Garasino, un cuadro intelectual del Ejército, autor de un libro en que defendió la presencia militar en cuestiones políticas (...). Garasino tenía además el cargo de subdirector. El tercer nombre del staff era Félix Garzón Maceda, un cordobés con muchos amigos militares, dueño de una radio em Córdoba. Figurava como assessor; era, en verdad, el nexo cotidiano entre el Estado Mayor del Ejército y Timerman. Los frentistas estaban representados por Mariano Montemayor, que se había ido de Primera Plana cuando el Frente fracasó (...). Por último, el conservador-liberal Álvaro Alsogaray actuaba como el vocero de los grupos económicos y los intereses financieros del exterior (in TARONCHER, 2004, p. 397-398).

Sobre estes colaboradores de Confirmado, cujas colunas eram publicadas de forma bastante irregular, afirma, por seu turno, Miguel Angel Taroncher:

Álvaro Alsogaray, ex ministro de economia de Frondizi y Guido, criticava los lineamientos estructurales y conyunturales de la economia radical; Carlos Florit, de filiación desarrollista, ex ministro de relaciones exteriores de Arturo Frondizi, analizaba temas de política internacional; el teniente coronel Alberto Garasino informaba sobre una de las principales cuestiones de interés (...) de Confirmado: los temas militares, y Rodolfo Martínez, ministro del interior de Guido, informaria sobre panoramas políticos desde uma perspectiva integracionista (TARONCHER, 2009, p. 170-171).

A partir da edição de número 26, em outubro de 1965, apareceriam de forma regular e permanente os artigos de Mariano Montemayor: "su misión será la de instigar, en forma directa, a las fuerzas armadas a derribar al presidente Illia” (TARONCHER, 2009, p. 171). 
A partir desses contatos pessoais e profissionais, Confirmado reivindicava, frente a seus leitores, uma posição privilegiada no que se referia à divulgação de temas, documentos e notícias dos bastidores da política nacional, de difícil acesso por parte de seus concorrentes no mercado jornalístico. Igualmente se propagavam nesse sentido os contatos especiais com membros das elites civis e militares que articulavam o golpe contra o governo radical (TARONCHER, 2009, p. 175). Significativo nessa direção é o fato de Timerman, em dezembro de 1965, passar a ser editor, deixando a direção de Confirmado a cargo do Comodoro Juan José Güiraldes. Escritor e ensaísta sobre temas gauchescos argentinos, Güiraldes era um militar e político nacionalista, que participara, como diretor da Aerolíneas Argentinas, do governo Frondizi e compusera os quadros da UCRI e do frentismo. No contexto, trabalhava pelo golpe contra Illia e propagava ser o general Onganía o chefe de Estado ideal para liderar o que punha como as reformas necessárias na economia e na política argentinas para superar o que denominava partidocracia. Concretizado o golpe, Timerman retomaria a direção do semanário.

Para além destes responsáveis pela articulação mais direta com o setor político, Timerman empregava em sua equipe técnica de redação um staff composto por jornalistas e escritores bastante experientes, como Alberto Rudni, Héctor Tomasini, Jorge Aráoz Badi, Osiris Chiérico, Edmundo Eichelbaum, Félix Luna, Luis Alberto Murray e Victorio Sánchez. A esses juntava-se um grupo que Carlos Ulanovsky classifica como de uma geração intermediária: Rodolfo Pandolfi, Armando Alonso Piñeiro, Agustin Mahieu, Osvaldo Ciezar, Enriqueta Souto e Horácio Verbitsky (2005, p. 241). Confirmado contava ainda com jornalistas recém iniciados e que consolidariam carreiras na imprensa argentina ao longo da década seguinte: Diego Barranchini, Oscar Delgado, Maria Angélica Molinari, Sergio Caletti e Pepe Eliaschev. De forma geral, os salários oferecidos por Timerman eram bastante atrativos na comparação com os principais concorrentes, inclusive Primera Plana.

O periódico contava com correspondentes permanentes em Paris, Roma e Washington: Enrique Raab, Héctor Kuperman e Nicolás Rivero. Empregava, para suas seções de noticiário nacional, os serviços da agência Tel Press, bem como o material fornecido com exclusividade para a América Latina pela agência Orbe Latinoamericana. Contava igualmente com serviços de correspondentes nos principais centros urbanos do interior argentino. As coberturas fotográficas nacionais ficavam a cargo dos prestigiosos fotojornalistas Jorge Miller e Williams 
Fredes, sendo empregados igualmente os serviços informativos fotográficos das agências Associated Press, Inter-Prensa e United Press.

As seções fixas da revista congregavam um amplo espectro de temas relativos à atualidade nacional e internacional, política, costumes e instituições: La Nación, El Mundo, Medicina, Religión, Justicia, Universidad, Arte, Música, Discos, Libros, Espetáculos, Televisón, Deportes, Entretelones e Economía. A partir da segunda edição, apareceriam novas seções especializadas e de aparições variáveis, tais como Sin Protocolo, na qual, em breves tópicos noticiosos, narravam-se acontecimentos do mundo político, artístico e cultural. Era igualmente o caso de Gente y Empresas, na qual se noticiavam diferentes atividades empresariais e a presença de grandes executivos em diferentes espaços de trabalho ou sociabilidade. Dessa forma, todas as seções, direta ou indiretamente, visavam ao público alvo da revista: os grupos de poder aquisitivo médio e alto da população argentina. No período em tela, a revista não chegou a superar a marca de 60.000 exemplares por edição, mas contava com algo em torno de cinco ou seis leitores por exemplar nesta franja de público (ULANOVSKY, 2005, p. 258).

Para além da controvérsia a respeito do quanto Confirmado havia sido fundada com a finalidade específica de constituir o campo de apoio ao golpe contra o governo Illia, sob encomenda do general azul Osiris Villegas, e a partir disso obter seu financiamento - o que de resto seria sempre negado por Timerman - a revista contava com espaço publicitário significativo. Por coincidência ou não, destacavam-se nesse espaço empresas petrolíferas estrangeiras e a indústria farmacêutica multinacional, ambas em confronto direto, no contexto, com a política econômica nacionalista e estatista de Illia, expressa na revisão dos contratos da Yiacimientos Petroliferos Fiscales (YPF) com empresas estrangeiras, os quais haviam sido celebrados no governo Frondizi, bem como na chamada Lei dos Medicamentos, pela qual o governo objetivava estabelecer mecanismos de controle estatal sobre o setor (SÁNCHEZ, 1983).

Após o golpe de 1966, a revista de Timerman alternaria as denominações Confirmado, Nuevo Confirmado e novamente Confirmado, para, em 1973, fundir-se com a revista Analisis, resultando na criação de Análisis Confirmado. De todo modo, no contexto aqui importante, Confirmado "fue una revista semanal de posturas extremas y poco sutiles en la campaña instalada en la opinión pública, alimentando el apoyo al golpe de estado de junio de 1966, objetivo para el cual, en rigor, había sido creada" (TARONCHER, 2009, p. 216). 
Carlos Ulanovsky, por seu turno, afirma ser absolutamente indiscutível o posicionamento pró-golpe das duas criações de Jacobo Timerman, Primera Plana e Confirmado. Todavia, trata o autor de estabelecer nuances importantes na atuação político-cultural das revistas no período pré e pós golpe - ambas sofreriam com a censura e com a consolidação ditatorial do novo ciclo de poder que contribuíram para implantar, inclusive com o fechamento de Primera Plana em 1969. Refere nesse sentido o autor:

a la manera de sus similares extranjeras, se denominaban 'revistas de influencia'. Propiciaban una ideologia liberal, compartida por el grueso de sus lectores (...). Apoyaron las novidades, las vanguardias estéticas, todas las formas artísticas y culturales de renovación y de la modernidad en el país y en el extranjero. Informaron en detalle sobre todas las censuras, juicios y condenas promovidas por el poder militar contra los creadores culturales. Revisaron importantes temas históricos de la época que estaban sepultados y sobre los que había mucha ignorancia: el peronismo, Eva Perón, Che Guevara, el 17 de octubre y muchos otros. Promovieron el conocimiento de grandes figuras culturales extranjeras, desconocidas o prácticamente desconocidas aquí, desde García Márquez hasta Marcuse. (...) A partir de 1967, aun con los partidos políticos prohibidos, comezaron a incluir entrevistas a sus dirigentes más conocidos (ULANOVSKY, 2005, p. 258-259).

Nota-se, assim, que Confirmado, não obstante o posicionamento explícito e direto pela derrocada do governo Illia em 1966, não deixou de atuar segundo os parâmetros básicos da imprensa informativa empresarial, fundados no liberalismo profissional - de modo geral incompatível com ordens ditatoriais de longo prazo - e no apelo à objetividade, alicerçado na categoria noticia.

\section{A Ditadura institucionalizada no Brasil - o exemplo e a ameaça}

Para o presente artigo, foram examinados todos os exemplares de Confirmado no período compreendido entre maio de 1965, mês de surgimento da revista, até junho de 1966, quando é perpetrado o golpe contra o governo de Arturo Illia, num total de 54 exemplares. $\mathrm{O}$ Brasil foi notícia em 12 exemplares, um índice de frequência $(22,2 \%)$ superior a qualquer outro país latino-americano no período considerado. 
Geralmente, as matérias, com extensões variadas, aparecem na seção especializada El Mundo, sempre marcadas por forte teor analítico-opinativo, o que marca o estilo da publicação, conforme acima discutido. As agências internacionais, com as quais trabalha a redação de Confirmado, não são referidas como fontes em nenhuma das matérias sobre o Brasil, aparecendo nessa condição o diário brasileiro Jornal do Brasil e, em duas ocasiões, enviados especiais.

O decreto do Ato Institucional número 2 (AI2) no Brasil constitui um marco no conjunto das matérias examinadas. A progressiva institucionalização da ordem ditatorial no país vizinho de fato empresta o tom analítico na construção narrativa da notícia. Todavia, pode-se perceber, no pré e no pós-AI2, as linhas de uma clara racionalização (THOMPSON, 1995, p. 82-83) tendente a constituir o sentido da solução autoritária no Brasil, por um lado, e, por outro, a colocar tal solução em contraste com a realidade política argentina.

Agente jornalístico claramente alinhado às forças golpistas civis e militares, como se viu, Confirmado constitui uma lógica potente da ditadura em marcha e consolidação no país vizinho, ao mesmo tempo em que constrói a imagem de um novo Brasil que, assim, robustecia sua condição de potência no cenário americano, em alarmante ameaça a uma Argentina enfraquecida pelas supostas debilidades de sua política externa e de suas estruturas político-institucionais, fraquezas as quais o governo Illia aparece sempre potencializando.

O Brasil é notícia na primeira edição de Confirmado. Neste período pré-AI2, a temática referencial gira em torno de uma dupla expectativa: as eleições presidenciais e estaduais marcadas para 1966 e o aprofundamento possível do processo de intervenção militar na política brasileira. A matéria de confirmado dá conta das movimentações dos candidatos potenciais, bem como das principais lideranças com direitos políticos já cassados, com destaque para Miguel Arraes, Juscelino Kubistchek e Carlos Lacerda, este posto como "uno de los artífices del derrocamiento de João Goulart"("Solo para militares: Veto a Candidatos em Brasil", 7 de maio de 1965, p.20), mas que no momento causava sérias apreensões ao núcleo do poder militar.

Nessa direção, o tom da notícia é marcado pela voz que ali se dá ao então ministro da Guerra brasileiro, Arthur da Costa e Silva, que surge afirmando: "'todo candidato a la elección de gobernador o de presidente recibirá su investidura siempre que las Fuerzas Armadas no lo impidan"" ("Solo para militares: Veto a Candidatos em Brasil", 7 de maio de 1965, p.20). Assim, pode concluir imediatamente o redator, 
na construção de uma expectativa como componente da notícia: "los eventuales candidatos que comienzan a manifestarse comprendieron rapidamente que la revolución militar, de ahora en adelante, creará claras fórmulas de perpetuación en el poder" ("Solo para militares: Veto a Candidatos em Brasil", 7 de maio de 1965, p.20. Grifo meu). A matéria apresenta um significativo parágrafo de conclusão, posto imediatamente após a informação sobre atos "terroristas" que começavam a se intensificar no país vizinho, como a explosão de uma bomba no diário O Estado de São Paulo:

la creciente intervención de las Fuerzas Armadas en el processo político brasileño no há alcanzado su culminación. Mas bien da cuenta de una paulatina ampliación de los limites atribuídos a su poder de vigilancia y a su capacidad de determinar los acontecimentos futuros. Esta experiencia militar en el campo político - unida a la batalla por sanear las finanzas - constituye un punto de referencia obligado, en las ultimas semanas, para los observadores de la realidad continental ("Solo para militares: Veto a Candidatos em Brasil", 7 de maio de 1965, p. 20).

Constitui-se assim um sentido para a consolidação da ditadura no Brasil para uma parcela potencial do público leitor argentino de Confirmado, por meio de variadas disposições discursivas. Dentre estas, a incorporação do significado do termo Revolução, associado à implantação institucional da ditadura, parece decisivo para a operação ideológica por meio da qual o liberalismo profissional, típico do campo da imprensa informativa empresarial, pode articular-se ao respaldo de uma ordem autoritária em consolidação. Alicerçada tacitamente nos princípios do anticomunismo, tal ordem pode aparecer com um dinamismo caracterizado por atributos positivos, tais como "poder de vigilância" e "saneamento" das finanças, postas estas no âmbito de uma sempre potente naturalização (THOMPSON, 1995, p. 87-89) do sistema socioeconômico capitalista, ao qual se associa a democracia como conceito ou valor essencial, defendido, assim, em última análise, para um "futuro" histórico. Particularmente para o público argentino, parece igualmente relevante a forma pela qual Confirmado constitui - tipicamente - a experiência brasileira como um "ponto de referência obrigatório" para os assim postos "observadores" da "realidade continental", disposição que evoca um sujeito abstrato do discurso jornalístico, capacitado a construir uma análise objetiva de uma ordem que se pode colocar como fática, convertendo desde sempre a notícia em acontecimento (SODRE, 2009; NORA, 1979). 
Essa perspectiva temática é, como se disse, mantida no período em que o Brasil é notícia antes da edição do AI 2. Nessa direção, Confirmado reproduz certa imagem internacional típica da política brasileira:

días atrás, el semanario londinense The Economist afirmaba, con aparente gravedad, que la política brasileña se guía por pautas tomadas del teatro clásico francés: largas declaraciones, amplios gestos, escasa acción. 'Sólo que - agregaba la revista - mientras Racine e Corneille resolvían el conflicto en el quinto acto, los políticos brasileños improvisan permamanentemente' ("Brasil Racine y Corneille dan Pautas Políticas", 10 de Julho de 1965, p. 16).

Aberta a matéria ao estilo New Journalism, Confirmado compõe a notícia acerca da realidade brasileira:

el centro del escenario es ocupado por el presidente Castelo Branco y los hombres de abril de 1964; con habilidad y prudencia, el primero intenta segurar que la revolución 'contra el comunismo y la corrupción' no se diluya luego de las prometidas elecciones de noviembre del año próximo. (...) Los protagonistas del derrocamiento de Goulart no son precisamente populares y el programa de deflación económica y financiera del ministro de Planificación Campos no tiene perspectiva de éxito antes de fin de año. La deflación no es una buena plataforma electoral en el Brasil ("Brasil - Racine y Corneille dan Pautas Políticas", 10 de Julho de 1965, p. 16).

Desse modo, parece posto um dos paradoxos da posição sustentada por Confirmado acerca da consolidação da ordem ditatorial no Brasil frente à situação argentina. A revolução contra o comunismo e a corrupção - estes dois termos postos genericamente na voz dos personagens centrais da cena - não é "popular" e pode, portanto, ser posta em questão pela liturgia fundamental da democracia representativa: as eleições. $\mathrm{O}$ liberalismo profissional que embasa o discurso vê-se na contingência de estabelecer uma franca oposição entre o processo eleitoral clássico e a defesa contextual de valores supostamente essenciais a uma ordem "democrática" perene, vale dizer, a luta contra o comunismo e a corrupção, bem como o respaldo a um programa governamental antiinflacionário, posto como inevitável para a salvaguarda de uma ordem econômica capitalista - sempre naturalizada -, e, todavia, uma péssima plataforma eleitoral. Os riscos do populismo associados ao rito eleitoral em um contexto crítico parecem ser a base da disposição discursiva, embora não ostentem uma aparição explícita na narrativa. 
A notícia de um encontro entre personagens emblemáticos coloca novamente o Brasil como tema em Confirmado. No final de agosto de 1965, os ex-presidentes Arturo Frondizi e Jânio Quadros encontravam-se na residência daquele, em Buenos Aires, para uma avaliação dos contextos políticos de seus países, com a presença da imprensa. A matéria em Confirmado é disposta em torno a uma fotografia de ambos os presidentes por ocasião do célebre encontro de Uruguaiana, em que ambos haviam firmado importante Ata para a cooperação Brasil-Argentina. A legenda parece significativa: "Frondizi y Quadros en Uruguayana: Golpes Militares para Brasil y la Argentina" ("Prognósticos. Cuando los Derrocados Analisan la situación", 26 de agosto de 1965, p. 14). Segundo os termos da construção da notícia, ambos os personagens traçam prognósticos bastante semelhantes para seus países, enquadrados em um contexto que consideram de grave crise socioeconômica na América Latina, cuja dimensão estrutural a política dos Estados Unidos não avaliaria corretamente, dada a estreiteza da Aliança para o Progresso.

Na voz de Quadros e Frondizi, surge a tensão política essencial do contexto: a possibilidade de saídas constitucionais frente à progressão das intervenções militares em ambos os países. Os prognósticos parecem apontar para possibilidades maiores no sentido da solução autoritária institucionalizada, sem que se descartasse por completo uma "saída eleitoral". Nesse sentido, Quadros aparece asseverando: "es muy posible que se vaya hacia la dictadura, pero no debe descartarse la posibilidad electoral" "Prognósticos. Cuando los Derrocados Analisan la situación", 26 de agosto de 1965, p. 14). Frondizi, por seu turno, afirma em paralelo: "Quizá pueda decirse (...) que en un plazo de aqui a dos años es más fácil que haya un golpe de estado con solución militar, que llegar a las elecciones" ("Prognósticos. Cuando los Derrocados Analisan la situación", 26 de agosto de 1965, p. 14). Os prognósticos assim postos parecem consolidar uma expectativa, por um lado, e, por outro, uma vez mais tecer uma lógica da institucionalização das intervenções autoritárias em marcha nos dois países, estando o Brasil então em clara "vantagem" diante de certa visão de uma parcela do público leitor argentino.

Em seção dedicada ao cinema, noticiando, com enviado especial, o festival internacional que se realizava no Rio de Janeiro, entre setembro e outubro de 1965, o Brasil ganhava destaque nas páginas de Confirmado ("Dios y el Diablo em la Tierra del Sol", 7 de outubro de 1965, p. 51). Curiosamente, a notícia, ocupando duas páginas em seção 
dedicada a eventos culturais, enquadrou a situação política brasileira frente à argentina dentro de certos padrões que viriam a tornar-se recorrentes no contexto examinado. O país vizinho, em franco processo de consolidação da ditadura, aparece, em contraste com a Argentina de Arturo Illia, ostentando posição internacional fortalecida por um projeto de desenvolvimento socioeconômico interno coeso e positivamente articulado. Nesse sentido, a matéria se abre afirmando:

luego de la caída de Jango Goulart, los diretores del cinema novo brasileño estuvieron proscritos e prófugos en su país. Sin embargo, poco tiempo después, los governantes de Brasil (...) comprendieron que esos intelectuales desconformes, com sus películas vitales y explosivas, ubicados en una posición de clara rebeldía social, eran uno de los productos más valiosos que Brasil podía mostrar al extranjero. Así se produjo una notable paradoja: el Banco de Guanabara (...) se transformó en el principal sostén económico para los films realizados por los jóvenes izquierdistas. Para un extranjero resulta incomprensible comprobar que la propaganda oficial destaca el éxito internacional de películas como Vidas Secas, de Nelson Pereira dos Santos, o Deus e o Diabo na Terra do Sol, de Glauber Rocha. (...) Pero no debe olvidarse el peculiar nacionalismo brasileño, ampliamente demostrado en el Festival: el cinema novo es un cine de izquierda, 'mais (sic) é nosso' ("Dios y el Diablo em la Tierra del Sol”, 7 de outubro de 1965, p. 51).

Apresentava-se assim ao público argentino de Confirmado o esboço de uma política cultural da ditadura em consolidação no Brasil, a qual, para além dos antagonismos políticos, apresentaria, segundo a disposição discursiva, um claro embasamento "nacional", no sentido da promoção oficial de uma indústria cinematográfica posta como autenticamente brasileira. Após expor a aceitação "lúcida" dos termos de tal política por parte dos principais realizadores ligados ao Cinema Novo, dando voz, nesse sentido, principalmente a Nelson Pereira dos Santos, o redator constrói o contraste com a situação do cinema argentino na relação com o poder público:

la experiencia vital de los jóvenes cineastas brasileños (...) impresionó a los solitarios representantes de la desalentada nouvelle vague argentina, presente em Rio. Rodolfo Kuhn, jurado de corto metraje en el certamen, susurró melancolicamente: '(...) aqui están unidos y luchan juntos'. Mientras tanto, cocteles o feijoadas diplomáticas reunían ocasionalmente a la delegacón argentina, en 
medio de la cual brillava la clásica incomunicación generacional. (...) Sin embargo, una sola evidencia los golpeaba a todos: el ejemplo de una lucha coherente por el desarollo de un nuevo cine, frente a la dramática impotencia de la industria para promoverse sin destruir las iniciativas renovadoras ("Dios y el Diablo em la Tierra del Sol", 7 de outubro de 1965, p. 51).

Conforme mencionado, esse padrão de construção discursiva, aqui aplicado à questão da indústria cinematográfica, tornar-se-á progressivamente recorrente na comparação entre as situações políticas brasileira e argentina. O leitor de Confirmado verá um Brasil, sob regime ditatorial, em progressiva vantagem sobre a Argentina no campo internacional, em função de uma assim posta articulação de um projeto nacional conduzido de forma coerente e integradora, como revelava o caso da incorporação a tal projeto do "esquerdista" e inovador Cinema Novo, como uma poderosa marca nacional no mercado mundial da indústria cinematográfica. Um Brasil com rumo assentado, embora nunca sem contradições, será assim contraposto a uma Argentina enfraquecida, fragmentada e à deriva sob o governo radical del pueblo. O país vizinho mais uma vez aparecia a um tempo como espelho e ameaça em uma ideologia vigorosa da solução autoritária na construção narrativa da notícia. É assim que pode concluir a matéria:

el Festival de Rio, con su declarada intención de converterse en la Capital Mundial do Cinema, prueba quizá la propensión brasileña a la hipérbole, pero permite al cinema novo una alentada audiencia mundial. Este hecho positivo, que asombró a los argentinos, puede agregarse a la capacidade insólita de Brasil para reunir los extremos más antagónicos en una síntese nacional ("Dios y el Diablo em la Tierra del Sol", 7 de outubro de 1965, p. 52).

A edição de 4 de novembro de 1965 será marcante na construção dessa imagem do Brasil em Confirmado. Nela veiculava-se a notícia da promulgação do AI2 no país vizinho, a qual segundo os termos da matéria, "no deja ninguna duda acerca del carácter dictatorial de la revolución brasileña" ("Brasil: la Dialéctica Revolucionaria", 4 de novembro de 1965, p. 18). A incorporação do conceito de "revolução" associado à ditadura na construção narrativa é novamente fundamental em seu possível efeito ideológico. Nesse sentido, Confirmado assim situa a relevância do Ato Institucional na consolidação do sentido da nova ordem autoritária: 
con el sacrificio de una fácil popularidade, con la segura confianza del capital extranjero y con la competencia de dirigentes como Roberto Campos - ministro de Planificacíon -, el Brasil comenzaba así a emerger del marasmo económico y a colocarse en condiciones de encararar la fundamental reforma de estructuras. El problema residía entonces en saber si la revolución tomaría la sienda electoralista y - a la larga - de compromiso con los viejos políticos, luego de haber saneado un tanto las finanzas y combatido otro tanto la corrupción, o si llegaba más a fondo y se decidía a encarar por si misma una tarea de proyeción histórica. (...) El influyente ministro de Guerra, general Arturo da Costa e Silva (sic) (...) pronunció un categórico discurso a causa de unas declaraciones del presidente de la Corte Suprema, Ribeiro da Costa. 'La revolución - afirmó es irreversible y no cesará de combatir, sin tregua al sistema que imperaba en el país antes del 31 de marzo de 1964'. El ministro se referia concretamente al 'sistema', con lo que le daba a la revolución su cabal sentido de profundidad ("Brasil: la Dialéctica Revolucionaria", 4 de novembro de 1965, p. 18).

Novamente, a consolidação da ordem ditatorial, apoiada pelo significado amplo do termo "revolução", é posta a um tempo como tarefa histórica de transformação de "estruturas" na defesa de um capitalismo - sempre naturalizado pela nomeação economia - "saudável" e bem inserido no mundo e como ruptura radical e necessária com o "velho sistema" político-partidário, apoiado formalmente na "velha" ordem constitucional, mas colocando em risco os pilares essenciais para uma ordem posta como essencialmente "democrática", em termos ocidentalistas, conforme aqui se vem discutindo. Parece significativa nesse sentido a forma pela qual essa construção discursiva integra a voz de Costa e Silva frente a "declarações" não explicitadas do presidente da Corte Suprema brasileira.

É assim que o texto de Confirmado pode asseverar a seu público leitor: "la segunda acta institucional (...) abre el campo para realizar una acción de gran aliento, sin demasiadas preocupaciones electoralistas y sin concesiones al mundo de la vieja politiquería, incluidos Lacerda y sus fieles" ("Brasil: la Dialéctica Revolucionaria", 4 de novembro de 1965, p. 18-19). É importante como a lógica da construção converte radicalmente o ritual eleitoral em "eleitoreirismo" e a própria atividade político-parlamentar em "politicagem".

A matéria qualifica a chamada repercussão internacional da edição do AI2 no Brasil como "díspar". É interessante para a presente análise o modo pelo qual Confirmado denomina "formalistas" os órgãos da 
imprensa informativa estrangeiros que de algum modo condenaram a consolidação da ditadura no Brasil e chama de "realistas" aqueles que conferiram apoio direto ou indireto àquela solução autoritária. Dentre estes, significativamente destaca-se o posicionamento do Washington Post, qualificado como notório órgão "kennedista", talvez para acentuar um certo caráter insuspeito de sua peça editorial no tocante a convicções democráticas:

resulta una ironía que en algun lugar de América Latina la reforma, largamente necesitada, sólo pueda realizarse, según parece, por parte de un gobierno fuerte. En algunos casos esa clase de gobierno há surgido de golpes militares. El Brasil es un ejemplo de la situación en que un régimen com base militar há procedido a governar con dedicación en terrenos donde los políticos han fracasado. Desde el punto de vista del interés americano en la modernización y cambio de estructuras, las reacciones doctrinarias contra la misión de los militares son poco realistas ("Brasil: la Dialéctica Revolucionaria", 4 de novembro de 1965 , p. 19)

$\mathrm{Na}$ esteira de tal enquadramento "realista" da ditadura no Brasil, Confirmado pode concluir no que se refere à repercussão internacional da edição do AI2: "la bolsa, el mundo empresarial y los círculos de inversionistas extranjeros acogieron con satisfación una medida que les permite avizorar un futuro estable, serio y encamiñado a proporcionar a la economía brasileña bases modernas y orgánicas" ("Brasil: la Dialéctica Revolucionaria”, 4 de novembro de 1965, p. 19). Tal inserção internacional positiva da "economia" brasileira sob a ditadura consolidada será, como se disse, uma das bases da operação ideológica que colocará o Brasil como "exemplo" e "perigo" para uma Argentina, posta sempre como fragilizada pela experiência de governo civil de Illia e pela inconsistência institucional da tutela militar então vigente.

Tecendo um prognóstico por sobre a notícia, Confirmado não prevê um futuro fácil para o novo regime que se consolidava no país vizinho: "la vieja política tiene tendido sus tentáculos dentro de la misma revolución, y el agudo empirismo de los políticos del país hermano los capacita para toda clase de maniobras envolventes" ("Brasil: la Dialéctica Revolucionaria", 4 de novembro de 1965, p. 19).

Todavia, o advento do AI2, assim noticiado, marcava o fim de um futuro brasileiro até então marcado pela tensão entre a consolidação da ordem ditatorial de 1964 e a possibilidade da saída eleitoral para a crise. $\mathrm{O}$ fechamento do regime no país vizinho mudará o tom das notícias a 
seu respeito em Confirmado, sem alterar, contudo, os fundamentos de uma possível ideologia da solução autoritária para a região.

Em novembro de 1965, reunia-se, no Rio de Janeiro, a Segunda Conferência de Chanceleres Americanos, foro deliberativo articulado ao sistema da Organização dos Estados Americanos (OEA). Confirmado noticia o evento através de enviado especial, Luis Alberto Murray ("América: entre el Desarrollo y la Soberania", 23 de novembro de 1965, p. 19-20), que assina a matéria informativa, o que não é praxe na revista, ao menos no período aqui considerado. Além da pauta usual, relativa a temas comerciais, a questão principal a ser discutida na Conferência dizia respeito à Segurança. Tratava-se de estabelecer as bases jurídicas para a criação de uma Força Interamericana de Paz, órgão multilateral da OEA que teria competência para deliberar sobre intervenções armadas em países da região sob ameaça de convulsão sociopolítica, ou, na linguagem corrente do período, sob risco de constituírem uma "nova Cuba". O tema era recorrente ao menos desde o estabelecimento do Tratado Interamericano de Assistência Recíproca (TIAR), mas tornara-se premente após a revolução castrista e o recrudescimento da agenda de segurança em Washington, com a recente intervenção na República Dominicana.

Segundo informa o enviado especial de Confirmado, em meio a observações sobre o clima chuvoso no Rio e a respeito de ditos espirituosos de diplomatas e jornalistas, ao estilo que marca a revista, haveria um bem estabelecido consenso sobre a criação do mecanismo multilateral de segurança. Este era visto como resposta à necessidade de respaldo político dos Estados Unidos para sua política continental, por um lado, e, por outro, como forma de dar voz e voto às demais repúblicas americanas sobre a questão. Dessa forma, a informação colase imediatamente a um posicionamento ancorado na objetividade:

ya es voz pública que en marzo del año próximo, en Washington, otra conferencia idéntica consagrará en la práctica lo que la actual va a dejar formulado. En esta alternativa, verdadera encrucijada histórica, se aprecia hasta qué punto los esquemas clásicos de la izquierda más o menos liberal han dejado de influir en la conducción latino-americana. Todavia es posible oir (entre periodistas exclusivamente) alusiones al 'imperialismo yanqui' y afines, en relación con esta reunión, pero entre quienes deben decidir no queda vacilación alguna. La mentalidad que en Buenos Aires podría ejemplificarse en el Partido Socialista Argentino (...) continuará denunciando lo que supone alineación latino-americana respecto 
de USA, pero sólo por cegueira o mala fe puede negarse la actual evidencia: a través de una aparente subordinación, varios países defienden sus propios intereses y su respectivo desarrollo nacional. (...) No habrá una segunda Cuba: esto es terminante y definitivo. Y, puesto que existe acuerdo general en impedirlo, tal misión será desempeñada con mayor eficiencia por una estructura multilateral ("América: entre el Desarrollo y la Soberania", 23 de novembro de 1965, p. 20. Grifo no original).

Ocioso sublinhar as disposições ideológicas da racionalização embasada na categoria notícia. Dá-se conta da existência efetiva de um consenso na Conferência, fundado em razões realistas, isto é, objetivas e, em larga medida, incontornáveis. Posições divergentes, associadas a uma "esquerda mais ou menos liberal", são qualificadas como não influentes na "atualidade" latino-americana e marcadas por "cegueira" ou "má fé", ao esgrimirem argumentos fundados em conceitos descolados da "realidade", tais como "imperialismo" e "alinhamento subordinado" aos Estados Unidos. Tal "subordinação", apenas "aparente", surge na construção discursiva como "evidentemente" fundamental para cada país latino-americano negociar positivamente com Washington os termos de seu próprio desenvolvimento nacional, por dentro e por fora de mecanismos multilaterais, como o que se encontrava em discussão no Rio de Janeiro.

Este último ponto, de resto, dará o tom predominante das abordagens de Confirmado sobre o Brasil pós-AI2. Em contraste com a Argentina, o Brasil, sob uma ordem ditatorial institucionalizada, surge fortalecido no cenário internacional, praticando uma política externa coerente e com vistas ao desenvolvimento nacional. É significativo, nessa direção, que a primeira página da matéria que noticia o encontro de chanceleres, tenha como centro uma fotografia do chanceler argentino Zavala Ortiz, com a legenda interrogativa: Zavala Ortiz - Sin Contradiciones? ("América: entre el Desarrollo y la Soberania", 23 de novembro de 1965, p. 19). Já na página seguinte, vê-se, igualmente centralizada, fotografia de Castello Branco em conversa com o secretário estadunidense Dean Rusk, com a legenda: Rusk y Castello Branco - Brasil sabe lo que quiere ("América: entre el Desarrollo y la Soberania", 23 de novembro de 1965, p. 20).

O texto da notícia fortalece o contraste de forma nítida. Sobre o pronunciamento de Castello Branco na Conferência, afirma-se: "el discurso del mariscal Castelo Branco careció (...) de alusiones sibilinas; con claridad casi cruda define cada punto sin rodeos ni 
sobre-entendidos" (“América: entre el Desarrollo y la Soberania”, 23 de novembro de 1965 , p. 20). Destacam-se, a seguir, os três pontos essenciais do discurso do presidente-ditador, os quais diziam respeito à desatualização do sistema da OEA sobre a questão de segurança, a necessidade de mecanismos militares específicos de combate à guerra revolucionária e o apoio decidido de Brasília à Força Interamericana visando a tal objetivo.

Já no tocante ao pronunciamento de Zavala Ortiz, assevera-se: “el discurso de Miguel Angel Zavala Ortiz puso de manifiesto, una vez más, las contradicciones internas del Poder Ejecutivo argentino, sobretodo en sus críticas muy poco veladas a la política económica de USA, y careció de toda referencia al punto fundamental de la conferencia" ("América: entre el Desarrollo y la Soberania", 23 de novembro de 1965,p. 20). O mais grave efeito de tais contradições residia, segundo a matéria, no fato de que a Argentina apoiava, tanto quanto o Brasil, a criação da Força Interamericana nos bastidores do Congresso, mas mostrava-se incapaz de explorar politicamente tal apoio em prol de seu próprio desenvolvimento e projeção internacional frente aos Estados Unidos, como o Brasil aparecia realizando. Este ponto fundamental, segue o texto, "dependerá, como cuanto sucede en el país, del mayor o menor acuerdo entre la Presidencia de la Nación y las Fuerzas Armadas" ("América: entre el Desarrollo y la Soberania", 23 de novembro de 1965 , p. 20).

A assim posta debilidade da tutela militar sobre a ordem política argentina do pós Revolución Libertadora, em contraste com a "revolução" brasileira, deixava abertas as contradições internas que enfraqueciam a posição internacional do país, particularmente frente aos Estados Unidos e ao rival histórico no cenário sul-americano. Parecia assim bem posta, uma vez mais, a construção ideológica no interior da notícia tendente a emprestar sentido para a institucionalização da solução autoritária na Argentina, posicionando-se o Brasil a um tempo como exemplo e ameaça potencial nessa direção.

Sempre nesse sentido, em abril de 1966, Confirmado noticia as repercussões de um pronunciamento do chanceler Zavala Ortiz a respeito de recente visita oficial a países asiáticos. É interessante notar que, antecedendo imediatamente essa longa matéria, encontra-se uma extensa análise acerca da notícia segundo a qual o general Juan Carlos Onganía, ex-comandante em chefe das Forças Armadas e futuro líder do golpe que deporia Arturo Illia em junho daquele ano, havia recusado a oferta do presidente para ocupar a embaixada argentina no 
Rio de Janeiro. Como Onganía há algum tempo não se pronunciava publicamente e tampouco falava à imprensa, Confirmado afirma haver realizado uma série de entrevistas com pessoas que haviam conversado com o general nas últimas semanas, para daí extrair seu posicionamento, não apenas quanto ao fato noticiado, mas a respeito da situação geral do país. De tais entrevistas, Confirmado expunha o pensamento do futuro líder golpista a respeito das instituições parlamentares e do governo Illia:

se manifiesta respetuoso del sistema, pero agrega que, en las actuales circunstancias, el Congreso no cumple una función útil desde el punto de vista nacional. Tampoco sirve - en su concepto el régimen liberal (...). Toda esta situación se agrava, en opinión de Onganía, (...) por la obsessiva fidelidad del presidente Illia (...) a un programa anticuado, que no tiene relación con los objetivos reales del país. El ex comandante en jefe opina que la responsabilidad de una quiebra de la legalidad no puede limitarse a un grupo o sector del país, sino que, en caso necesario, debe ser asumida por todos los habitantes en su conjunto, 'por cada argentino que quiere que el país cumpla su destino como nación' ("Las Entrevistas de Onganía", 14 de abril de 1966, p. 14).

Significativamente para a presente análise, é colado à veiculação jornalística de tal exortação nacional ao golpe - inclusive com voz na primeira pessoa do líder militar então "em silêncio" - que se põe, como referido, o longo exame da política externa argentina embasado na notícia acerca da repercussão de pronunciamento recente de Zavala Ortiz ("Delirios - La Política Argentina en Asia y América", 14 de abril de 1966, p. 14-16). O dito exame é inteiramente fundado em uma comparação fundamental:

en la última semana se conocieron ya las primeras reaciones al discurso del canciller Zavala Ortiz sobre su viaje a Asia. Las que pudieron recogerse en los medios militares fueron especialmente críticas, ya que compararon las tesis del ministro de Relaciones Exteriores de la Argentina con las presentadas por Vasco Leitão da Cunha, ex canciller brasileño ("Las Entrevistas de Onganía", 14 de abril de 1966, p. 14-15).

A matéria coloca, como se vê, os "meios militares" como sujeito que realiza a comparação entre as políticas exteriores argentina e brasileira, em mais uma manifestação das relações jornalísticas privilegiadas que 
Confirmado afirma manter com tais meios, conforme acima aludido. Vale a pena acompanhar por inteiro os termos da comparação:

el ministro Zavala Ortiz pretende que, gracias a su acción, la Argentina se há lanzado a la conquista del mercado asiático. Algunos oficiales de las Fuerzas Armadas comparaban esta pretensión con este hecho: a fines de 1965 el ex canciller brasileño Vasco Leitão da Cunha, que actualmente se desempeña como embajador en Washington, había disertado en la Escuela Nacional de Guerra de la Argentina sobre la política exterior de su país frente a la integración de América Latina. Explicando la estrategia del Brasil afirmó que esta se basaba en círculos concéntricos de intereses: primero, Brasil; después, América Latina; luego toda América; más tarde, Occidente, y, por último, el mundo. Los brasileños - explicó con toda franqueza - quieren lograr una integración económica latino-americana porque buscan la complementación industrial con la Argentina ("Las Entrevistas de Onganía", 14 de abril de 1966, p. 15).

A comparação posta na voz de oficiais argentinos é bastante clara: de um lado, uma política tão pretensiosa quanto vaga; de outro, objetivos realistas e progressivos, dispostos segundo os princípios geopolíticos dos "círculos concêntricos", bastante conhecidos nos meios de formação da alta oficialidade militar em ambos os países, os quais no Brasil embasavam a obra de Golbery do Couto e Silva e orientavam o projeto Brasil-Potência (COUTO; SILVA, 1981). Mais grave se torna a comparação diante da explicação do desdobramento potencial da política brasileira para a Argentina:

en otras palabras, eso quiere decir que el Brasil, como país más desarrollado, montaria una poderosa industria pesada y la Argentina sería proveedora de materias primas y produtos alimenticios, en una aplicación de la divisón internacional del trabajo a escala regional, como lo propugnado por el economista norteamericano Walt Rostow ("Las Entrevistas de Onganía”, 14 de abril de 1966, p. 15).

Ficava assim uma vez mais atualizada a figura clássica, central no pensamento militar (VILLEGAS, 1975), do "perigo brasileiro" para a Argentina, certamente agravada pela definição institucional da ditadura no país vizinho e a consequente consolidação da presença das Forças Armadas no núcleo do poder estatal em Brasília. Novamente o Brasil era exemplo e ameaça em uma ideologia da solução autoritária nas páginas de Confirmado. A narração do contraste entre as reações civis e militares à conferência de Leitão da Cunha é expressiva nessa direção: 
cuando terminó el discurso de Leitão da Cunha, los funcionarios civiles del gobierno argentino que estaban presentes aplaudieron, mientras los militares optaron por quedarse de brazos cruzados; un momento después, los últimos se acercaron a los primeros y les preguntaron si habian entendido algo y, en ese caso, si estaban de acuerdo con que la Argentina tuviera un papel subordinado en América Latina. Exaltado, un general llegó a decir entonces: ustedes no comprenden nada ni van a comprender nunca nada' ("Las Entrevistas de Onganía”, 14 de abril de 1966, p. 15).

A racionalização não poderia ser mais explícita no respaldo à avaliação militar em seus dois pontos básicos: os riscos para a Argentina de um projeto de expansão brasileiro na América Latina e a ingenuidade ou desconhecimento desse cenário alarmante por parte dos funcionários civis do governo Illia, cujo aplauso a narrativa torna quase escandaloso. A avaliação própria de Confirmado sobre a fala do chanceler do governo radical, associada à conferência do ex-ministro brasileiro bem como à reação "civil" a ela, é, entretanto, ainda mais grave do que aquela do "general exaltado":

el reciente mensaje de Zavala Ortiz parece indicar que los funcionarios radicales no estaban distraídos cuando aplaudieron al diplomático brasileño ni obraron movidos exclusivamente por un exceso de cortesia internacional. La alocución del canciller fija una meta aproximadamente utópica para la expansión del comercio internacional argentino - el mundo -, mientras que Brasil se concentra en América Latina y trata de extraer, en esa región, todos los beneficios posibles para su política ("Las Entrevistas de Onganía”, 14 de abril de 1966, p. 15).

A questão era, portanto, a ausência de uma política exterior realista no governo civil, derivando daí uma assumida concordância com os termos da política brasileira, a qual parecia, à diplomacia do partido radical del Pueblo, não afetar a posição internacional de Buenos Aires, ou mesmo, de algum modo, favorecê-la.

Ao estilo da revista, a matéria prossegue associando a posição de Zavala Ortiz àquela do marido de uma anedota, que, em consulta ao psiquiatra, refere que todas as tarefas "menores" da casa, como organizar o orçamento, educar os filhos, planejar atividades, eram realizadas pela esposa, enquanto ele próprio tratava de questões "de fato" relevantes, como convocar a Assembleia das Nações Unidas e declarar a guerra... Após desenvolver essa crítica ácida ao que julga ser o caráter "utópico" 
e irrealista da diplomacia do governo Illia, a matéria se fecha com a conclusão segundo a qual "Zavala Ortiz sería el canciller que el Brasil designaría, se pudiera, en la Argentina" ("Las Entrevistas de Onganía", 14 de abril de 1966, p. 16).

Essa mesma linha de entendimento quanto ao "perigo brasileiro" segue e se desenvolve em edições posteriores de Confirmado. Noticiando as repercussões de um discurso-denúncia do deputado por Santa Fé, Hector García Solá, acerca do projeto de construção da usina termelétrica El Chocon-Cerros ("Satelismo - La Carrera entre Brasil y Argentina", 28 de abril de 1966, p. 13), a revista volta a se ocupar do tema, de forma alarmante, principalmente, segundo o próprio texto, para os meios militares argentinos.

Faz-se inicialmente uma resenha dos principais pontos informativos do dito discurso. Segundo refere a matéria, o deputado alertara para a relevância do fato de que o ex-embaixador estadunidense no Brasil, Lincoln Gordon, fora nomeado como novo secretário para assuntos latino-americanos do Departamento de Estado, substituindo o célebre economista Walt Rostow. Ao fato agregava-se que o senador norteamericano William Fullbright havia recentemente manifestado a posição segundo a qual o Brasil deveria desempenhar uma posição de liderança na América Latina. Na forma de uma rede de fatos entrelaçados, o deputado referia ainda que, com a ajuda dos Estados Unidos, o Brasil dos militares construía as usinas de Três Marias, Paulo Afonso, Furnas e Jupiá, cada uma delas com capacidade equivalente a El Chocón. Seguindo essa teia de fatos, ao serem concluídas as obras de Sete Quedas, conjuntamente com o Paraguai, a usina teria dez vezes a capacidade de El Chocón. Denunciava ainda o deputado, com voz nas páginas de Confirmado, que há poucos dias iniciaram-se tratativas entre funcionários norte-americanos e empresários brasileiros, em São Paulo, com vistas à fabricação, em solo do país vizinho, de aviões militares a turboélices QU-10 (sic). Informava-se ainda a existência de um projeto para o desenvolvimento siderúrgico na América Latina, de cuja primeira fase a Argentina estaria excluída e, em uma segunda etapa, o Brasil já seria o centro fabril do subcontinente.

A trama assim posta se concluía com a observação explícita do redator da matéria:

en realidad, de acuerdo con las prevalecentes ideas del economista Walt Rostow, la estrategia de USA impulsa la división del trabajo, a escala regional, en América Latina. Esa política hace indispensable 
sostener en la Argentina al gobierno del presidente Illia, quien está de acuerdo con las tesis de Rostow; si eses planes tienen éxito, la Argentina quedará postergada al papel de satélite del Brasil ("Las Entrevistas de Onganía", 14 de abril de 1966, p. 16).

Os termos da narrativa que Confirmado reproduz e potencializa como agente jornalístico reforçam o evidente potencial ideológico de emprestar sentido à intervenção militar contra o governo Illia, com a imagem de um Brasil-potência regional ao centro. Parece evidente a relação que ali se constrói entre a consolidação do regime ditatorial no país vizinho e as supostas relações privilegiadas deste com os Estados Unidos, que assim o teriam "eleito" para a condição definitiva de líder regional, em uma atualização de termos clássicos do pensamento geopolítico argentino, dominante na concepção militar das relações internacionais do país- com destaque, nessa perspectiva, para a questão energética e industrial-militar. Novamente, os militares argentinos são postos na condição genérica de líderes indispensáveis de uma reação nacional diante dos "planos" de Washington-Brasília, com os quais estaria plenamente de acordo, sem que se diga exatamente o porquê, $o$ governo civil de Arturo Illia.

Por outro lado, as matérias de Confirmado a respeito da política interna do Brasil seguem absorvendo inteiramente o conceito de revolução, conforme acima discutido. Novamente se analisa o confronto inevitável desta com a "velha política", ao noticiar-se a resolução da questão sucessória em torno do nome de Costa e Silva ("Brasil - Sin posibilidad de sorpresas", 5 de maio de 1966, p. 36-37). Claramente em tom de respaldo, a matéria retoma os pontos básicos das ações revolucionárias sob a liderança de Castelo Branco, com destaque para o AI2 e seu desdobramento recente, o bipartidarismo, caracterizado como o princípio da "etapa final de la institucionalización de la revolución de marzo de 1964, que terminó con la azorada carrera de João Goulart". E igualmente o AI3, "el instrumento maestro de la revolución" ("Brasil - Sin posibilidad de sorpresas", 5 de maio de 1966, p. 36) que determinava a eleição indireta para a presidência no próximo 3 de outubro. A "preocupação" segue sendo a ausência de base popular para o regime, o que se reforçava pela política saneadora de Roberto Campos, posta sempre como "correta e necessária", mas com desdobramentos sociais negativos, sobretudo no tocante ao poder aquisitivo dos salários. É assim que a matéria se conclui, com especulação a respeito de uma potencial populari- 
dade de Costa e Silva e a retomada de um ponto básico do "perigo brasileiro":

muchos brasileños estiman que Costa e Silva no es ajeno a las frustraciones populares; recuerdan su orígen humilde (...) y destacan una faceta de su carácter que lo distingue del frío Castelo Branco; una interesante carga emocional. Finalmente contará con el aval económico de USA; el actual subsecretario de Estado para asuntos latino-americanos, Lincoln Gordon, era embajador en Brasil cuando las Fuerzas Armadas decidieron derrocar a João Goulart; la intervención de Gordon en aquella oportunidad le convertió en el tutor ante Washington, de la revolución. Una posición que será aprovechada sin duda por Costa e Silva, heredero del movimento ("Brasil - Sin posibilidad de sorpresas", 5 de maio de 1966, p. 37).

Confirmado seguiria em outras edições com essa preocupação quanto à ausência de base popular efetiva para a sustentação a longo prazo da Revolução brasileira ("Brasil - La Ambición de los Cuatro Generales", 26 de maio de 1966, p. 31-32), sobretudo em virtude da crise econômica e do programa de "austeridade" de Roberto Campos, enquanto previa ações positivas nesse sentido por parte do futuro presidente Costa e Silva e intensificava sua postura permanente de apoio à Revolução semelhante em seu país.

Se no plano da política interna, a Revolução exemplar no país vizinho tinha sérios desafios a enfrentar, na esfera da política externa, seus êxitos mostravam-se cada vez mais evidentes em Confirmado. E, como se tem discutido, exatamente em virtude tais êxitos, agigantava-se o "perigo brasileiro" para uma Argentina fragilizada pela assim posta inoperância do governo civil.

Às vésperas do golpe que derrubaria Arturo Illia e implantaria a Revolución Argentina sob Ongania, Confirmado noticiava que "una vez más, la política exterior brasileña parece haber ganado una importante batalla a la diplomacia argentina" ("Diplomacia - Una Vez Más, los Brasileños en Adelante", 16 de junho de 1966, p. 18-19). Tratava-se, segundo informa a matéria, da obtenção por parte do Brasil de apoio financeiro e tecnológico dos Estados Unidos para a implantação de uma "importante" indústria armamentista no país vizinho. Segundo a matéria, tal indústria abasteceria completamente as necessidades das Forças Armadas brasileiras e ainda produziria para o mercado exterior, na América Latina e nos Estados Unidos, particularmente para o palco vietnamita. 
A matéria segue afirmando que "según se desprende de eso, el gobierno de Washington no parece impresionado por el hecho de que Brasil esté regido por un gobierno militar que há derrocado a un governante constitucional y que, además, prepara su continuidad en el mando" (Diplomacia - Una Vez Más, los Brasileños en Adelante", 16 de junho de 1966, p. 18). Após reforçar a informação de que industriais de São Paulo já contavam como certo o financiamento norte-americano para a instalação de fábrica de aviões militares, após o regresso dos Estados Unidos de Vitorio Ferraz, presidente da Comissão Permanente de Mobilização Industrial paulista, Confirmado reconstrói o contraste preocupante para a Argentina. Em missão oficial nos Estados Unidos, o brigadeiro Romanelli trouxera de volta à Argentina apenas a advertência de que Washington veria com maus olhos uma intervenção militar para derrubar o governo Illia. Confirmado qualifica tal advertência como evidente interferência em assuntos domésticos argentinos e denuncia que o fato fora apresentado pelo governo como sendo perfeitamente "normal". Desse tratamento díspar para a Argentina e o Brasil por parte dos Estados Unidos e a inoperância governamental em Buenos Aires, segue a advertência do redator da matéria:

mientras tanto, los militares brasileños están rapidamente consolidando un eje con Washington cuyas consecuencias son imprevisibles y que, de acuerdo con la lógica de los acontecimentos, puede significar que Brasil ingresse luego (...) en el conclave de países que manejan la política internacional. Su desarrollo industrial e tecnológico llevaría a los militares brasileños a solicitar, según señalo un diario que se publica en San Pablo, una zona de influencia en América Latina ("Diplomacia - Una Vez Más, los Brasileños en Adelante", 16 de junho de 1966, p. 19).

Poucos dias após essa edição de Confirmado, uma nova intervenção militar na ordem política argentina derrubaria o governo Illia, com o projeto inicial de consolidar o processo iniciado em 1955, com a deposição de Perón. A construção narrativa, aqui examinada, das notícias acerca da institucionalização da revolução brasileira, associada ao suposto sucesso ameaçador de sua política de expansão internacional, pode, assim, ser vista como uma expressão marcante da reprodução, no campo jornalístico, de um sentido possível para essa solução autoritária. Sentido ao qual podia associar-se, mesmo que de forma circunstancial, o liberalismo profissional que constitui o fundo doutrinário daquela possível atuação ideológica. 


\section{Referências}

ALLEYNE, Mark D. International Power and International Comunication. London: Macmillan Press, 1995.

ALSINA, Miquel R. La Construcción de la Noticia. Barcelona; Buenos Aires: Paidós, 1996.

BANDEIRA, Moniz. Conflito e Integração na América do Sul Brasil, Argentina e Estados Unidos da Tríplice Aliança ao Mercosul 1870-2003. Rio de Janeiro: Revan, 2003.

. Estado Nacional e Politica Internacional na América Latina. O Continente nas Relações Argentina-Brasil (1930-1992). Brasília: Ed. UNB, 1993.

BERNETTI, Jorge Luis. El Periodismo Argentino de Interpretación en los Años 60 y 70. El Rol de Primera Plana y La Opinión. In: IV Congreso ALAIC. Recife, set. 1998.

CANTIS, Mario S. La Caída de los Tres Gobiernos Radicales. Buenos Aires: Centro de Estudios Unión para la Nueva Mayoría, 1995.

CAVLAK, Iuri. As Relações entre Brasil e Argentina no Início da Guerra Fria. História Debates e Tendências, Passo Fundo, v. 6, n. 2, 2007.

COUTO e SILVA, Golbery do. Conjuntura Política Nacional. O Poder Executivo \& Geopolítica do Brasil. Rio de Janeiro: J. Olympio, 1981.

DA ORDEN, M. Liliana; PIRRO, Julio César M. (Comp.). Prensa y Peronismo. Discursos, Prácticas, Empresas. Rosario: Prohistoria Ediciones, 2007.

DE RIZ, Liliana, La Politica en Suspenso 1966/1976. Buenos Aires: Paidós, 2000.

DÍAZ, Marcela. Industrias Culturales y Formas de Identificación Política. Primera Plana y su Rol en la Caída de Illia In: LLAIRÓ, Maria de Monserrat (Comp.). El Gobierno de Arturo Illia y la Restauración Institucional. Las Relaciones Económicas Internacionales y la Crisis de Gobernabilidad (1963-1966). Buenos Aires: Ediciones Cooperativas, 2007.

DONGHI, Tulio H. La Democracia de Massas. Buenos Aires: Paidós, 2000.

FAUSTO, Boris; DEVOTO, Fernando. Brasil e Argentina: Um Ensaio de História Comparada. São Paulo: Ed. 34, 2004.

FREDERICK, Howard H. Global Communication and International Relations. California: Wadsworth Publishing Company, 1993.

FROTA, Luciara Silveira de Aragão e. Brasil-Argentina: convergências e divergências. Brasília: Senado Federal, 1991.

GAMBINI, Hugo. Historia del Peronismo. La Violencia (1955-1983). Buenos Aires: Vergara Editor, 2008.

GOLDSTEIN, Gisela. Do jornalismo politico à indústria cultural. São Paulo: Summus, 1987.

GOLDWERT, Marvin. Democracy, Militarism and Nationalism in Argentina, 19301966. Austin e Londres: University of Texas Press, 1972.

LLAIRÓ, Maria de Monserrat (Comp.). El Gobierno de Arturo Illia y la Restauración Institucional. Las Relaciones Económicas Internacionales y la Crisis de Gobernabilidad (1963-1966). Buenos Aires: Ediciones Cooperativas, 2007. 
LLAIRÓ, Maria de Monserrat; SIEPE, Raimundo. Frondizi - un nuevo modelo de inserción internacional. Buenos Aires: EUDEBA, 2003.

NORA, Pierre. O retorno do fato. In: LE GOFF, Jacques; NORA, Pierre. História: Novos Problemas. 2. ed. Rio de Janeiro: F. Alves, 1979.

PANDOLFI, Rodolfo; GIBAJA, Emilio. La democracia derrotada. Arturo Illia y su Época. Buenos Aires: Lumiere, 2008.

PIÑERO, Elena T. Medios de Comunicación y representación política: el caso de Primera Plana (1962-1966). In: Temas de Historia Argentina y Americana, UCA, Facultad de Filosofia y Letras, n. 1, nov. 2002.

PIZARRO, A. Marcela. El "Mundo” de la Prensa Argentina. Que es noticia Internacional para La Nación y Clarín. Buenos Aires: Universidad Austral, 2008.

POTASH, Robert, El Ejercito y la politica en la Argentina 1962-1973. Buenos Aires: Ed. Sudamericana, 1994. Vol. 2.

RAPOPORT, Mario; LAUFER, Rubén. Os Estados Unidos diante do Brasil e da Argentina: os Golpes Militares da Década de 1960. Revista Brasileira de Política Internacional, n. 43, 2000.

ROMERO, Luis A. Breve Historia Contemporánea de la Argentina. Buenos Aires: Fondo de Cultura Económica, 2004.

SÁNCHEZ, Pedro. La Presidencia de Illia. Buenos Aires: Centro Editor de América Latina, 1983.

SCENNA, Miguel. Argentina-Brasil Cuatro Siglos de Rivalidad. Buenos Aires: Ed. La Bastilla, 1976.

SCIRICA, Elena. Proscripción, Modernización Capitalista y Crisis. Argentina (19551966). In: SCALTRITTI, Mabel S. et al. Historia Argentina Contemporánea. Pasados Presentes de la política, la Economía y el Conflicto Social. Buenos Aires: Dialektik Editora, 2008.

SIRVÉN, Pablo. Perón y los Medios de Comunicación. La Conflictiva Relación de los Gobiernos Justicialistas con la Prensa (1943-2011). Buenos Aires: Sudamericana, 2011.

SODRÉ, Muniz. A Narração do Fato. Notas para Uma Teoria do Acontecimento. Petrópolis: Vozes, 2009.

SPINELLI, Maria E. Ideas Fuerza en el Debate Político Durante los Años de la Libertadora 1955-1958. Estudos Sociales, n. 24, 2003.

TARONCHER, Miguel A. Periodista y Prensa Semanal en el Golpe de Estado del 28 de Junio de 1966: La Caída de Illia y la Revolución Argentina. Tese (Doutorado em História Contemporánea) - Universitat de Valencia, Valencia, 2004.

. La Caída de Illia. La Trama Oculta del Poder Mediático. Buenos Aires: Javier Vergara Ed., 2009.

THOMPSON, John B. Ideologia e Cultura Moderna. Teoria Social Crítica na Era dos Meios de Comunicação de Massa. Petrópolis: Vozes, 1995.

THUSSU, Daya K. International Communication: Continuity and Change. London, New York: Oxford University Press, 2000. 
ULANOVSKY, Carlos. Paren las Rotativas. Diarios, Revistas y Periodistas (19201969). Buenos Aires: Emecé Editores, 2005.

VILLEGAS, Osiris G. Tiempo Geopolitico Argentino. Buenos Aires: Pleamar, 1975.

Recebido: 10 de dezembro de 2015

Aprovado: 27 de fevereiro de 2016

\section{Autor/Author:}

HELDER GORDIM DA SILVEIRA <helders@pucrs.br>

- Doutor em História pela Pontifícia Universidade Católica do Rio Grande do Sul (PUCRS). Professor do Departamento de História e do Programa de Pós-Graduação em História da PUCRS. A experiência na área apresenta ênfase em História da América Contemporânea e História das Relações Internacionais do Brasil, publicando livros e artigos principalmente nos seguintes temas: relações internacionais do Brasil República no sistema interamericano, imprensa e intelectuais nas relações internacionais do Brasil, relações políticas Argentina-Brasil. Autor e organizador de diversas publicações, com destaque para Argentina X Brasil: A Questão do Chaco Boreal (EdiPUCRS, 1997), De Vargas aos Militares - Autoritarismo e Desenvolvimento Econômico no Brasil (EdiPUCRS, 2014) e Dimensões do Poder História, Política e Relações Internacionais (EdiPUCRS, 2015).

- PhD in History by the Pontificia Universidade Católica do Rio Grande do Sul (PUCRS). He is a Professor of the History Department and the Graduate Program in History at PUCRS. His research experience has emphasis in American Contemporary History and History of Brazil's International Relations, publishing books and articles mainly focused on the following subjects: international relations of the Brazilian Republic in the Inter-American system, press and intellectuals in the international relations of Brazil, political relations between Brazil and Argentina. He is the author of Argentina X Brasil: A Questão do Chaco Boreal (EdiPUCRS, 1997), De Vargas aos Militares - Autoritarismo e Desenvolvimento Econômico no Brasil (EdiPUCRS, 2014) and Dimensões do Poder História, Politica e Relações Internacionais (EdiPUCRS, 2015). 